\title{
Further studies on evaluation of the toxicity potential of Terminalia catappa Lin. Combretaceae leaf extract: effects on the histology, liver enzymes, and haematology profile of albino rats
}

\author{
Chika B. Ikele* , Elijah Okwuonu and Anya N. Ijem \\ Department of Zoology and Environmental Biology, University of Nigeria, Nsukka, Enugu State, Nigeria
}

Received: March 21, 2020; Revised: Dec 12, 2020; Accepted: Dec 21, 2020

\begin{abstract}
There is a global utilization of Terminalia catappa as a medicinal plant. In this study, the effect of aqueous leaf extract of Terminalia catappa (ALETA) on the haematological profile, liver function enzymes, and histology of some organs in albino rats was examined. Seventy-two healthy albino rats were randomly distributed into four groups (A-D) in 6 rats per triplicate. The normal control received $1 \mathrm{ml} / \mathrm{kg}$ of deionized water while groups B-D received 150, 300, and $450 \mathrm{mg} / \mathrm{kg}$ ALETA, respectively for 21 days. Minor cytoplasm vacuolation, focal necrosis, and dilated sinusoids were observed in the liver tissue. The kidney showed minor degenerative changes characterized by few shrunk glomeruli while no tissue damage was observed in the heart tissue and minor passive congestion was observed in the pyloric stomach. The packed cell volume (PCV), red blood cell (RBC), haemoglobin (HB), neutrophils (N), eosinophils (E), monocytes (M), lymphocytes (L), and means cell haemoglobin $(\mathrm{MCH})$ responded significantly $(\mathrm{p}<0.05)$ to treatment dosage. Meanwhile, the increased aspartate aminotransfarase (AST), alanine aminotransfarase (ALT), acid phosphatase (ACP) and alkaline phosphatase (ALP) were an indication of compromised liver function by the ALETA. There is a need for safety assessment, regulation, and intake of Terminalia catappa as a medicinal herb.
\end{abstract}

Keyword: Terminalia catappa, histopathology, haematology, liver enzymes, Rattus norvegicus

\section{Introduction}

Globally, fruit nutriments have beneficial health therapeutic and economic benefits (Venkatalakshmi and Brindha 2016). Indian almond seed, Terminalia catappaLinn (family Combretaceae) is a plant species with good records of medicinal importance associated with its chemical constituents. In Nigeria, the most popularly used plant parts are commonly referred to as 'fruit' by some local folks. The seeds and leaf of the plant mostly contribute to a high percentage of waste in the environment without being utilized more effectively for the benefit of society. Indian almond is popularly used as a herbal treatment for management of diabetes mellitus (Divya et al, 2018, Biswas et al, 2011, Koffi et al, 2011, Nagappa et al, 2003,). It is also used as analgesic (Mohale et al, 2008), for the alleviation of inflammation (Lin et al, 1997), etc. Most often, the fruit parts (kernel endocarp and fleshy mesocarp) of $T$. catappa are consumed roasted, raw, and sundried. Other plant parts such as the roots, barks, and leaf are used in the treatment of different ailments such as malaria (Mudi and Muhammed, 2009), respiratory disorders (asthma) (Raj et al, 2013), hypertension (Odugbemi, 2008), and as an antiretroviral (Alka et al, 2016). They possess therapeutic components that increase the potential use similar to conventional drugs. Several studies have reported that $T$. catappacan exert a multitude of effects such as anticancer (Shanehbandi et al, 2019; Lee et al, 2019) antimetastatic (Yang et al, 2010, Chu et al, 2007), antioxidant (Kumar et al, 2018, Krishnaveni et al, 2014), antimicrobial (Kumar et al, 2018), antidiabetic (Koffi et al, 2011, Ahmed et al, 2005, Lin et al, 1997), aphrodisiac (Ratnasooriya and Dharmasiri, 2000), antinociceptive (Ratnasooriya et al, 2002), and hepatoprotective (Kinoshita et al, 2007.

Globally, there is an increase in the intake of medicinal plants (mostly self-prescribed by consumers) without complying with World Health Organization (WHO) recommendations and guidelines. It is worthy of note that increased utilization of medicinal plants necessitated the WHO to provide the recommended intake per time to avoid negative/or side effects (WHO, 2004, WHO, 1998). Most plant materials can be taken indiscriminately or wrongly prescribed as prophylaxis against diseases. The safety regulation of global phytopharmaceutical products is paramount, essential, and implemented to avoid toxicity or adverse effects on the human body. In Nigeria, most herbal drugs are produced and consumed indiscriminately by local folks irrespective of strict regulations. However, despite the extensive use of herbs, there is a need to add to knowledge scientific proof validating their safety, efficacy, and usage. Histopathological assessment is a marker considered as a useful indicator for assessing the abnormal health effects of environmental materials on the living system (Arsad et al., 2014). Possibilities of organ toxicity

\footnotetext{
* Corresponding author e-mail: chika.ikele@unn.edu.ng.
} 
(nephrotoxicity, hepatotoxic, etc.) cannot be overruled on the unpredictable intake of plant products. Blood regulation at a normal range elicits homeostatic mechanism, and changes in the blood parameters. Liver enzymes are an indicator of the deleterious effect of chemical products. Moreover, the therapeutic uses of aqueous leaf extract of $T$. catappa (ALETA) have been scientifically supported by effects in malaria (Mudi and Muhammed, 2009), respiratory disorders (asthma) (Raj et al, 2013), and hypertension (Odugbemi, 2008), However, there is a need to promote more information on the histological, hematological, and liver enzyme alterations mediated by this plant extract. In this study, albino rats, Rattus norvegicus have been used to obtain such information.

\section{Materials and Methods}

\subsection{Experimental Animal}

Seventy-two healthy male albino Wistar rats weighing between 150-200g were used for the study. The animals were procured from the animal rearing facility of the Department of Zoology and Environmental Biology, University of Nigeria, Nsukka, and housed in wellventilated cages. Animals were acclimatized for two weeks and fed with standard pellets (Top Feeds, Plc Nigeria) with access to water ad libitum and maintained at different standard laboratory conditions, temperature $\left(25 \pm 2^{\circ} \mathrm{C}\right)$,

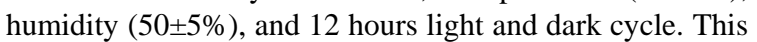
study was carried out following ethical guidelines for animal welfare by the Faculty of Biological Sciences, University of Nigeria, Nsukka.

\subsection{Plant material and preparation}

Whole plant leaf $(4 \mathrm{~kg})$ of Terminalia catappa were obtained from the Botanical garden of Plants Science and Biotechnology, University of Nigeria. The leaf was authenticated by a plant taxonomist in the Herbarium of Plant Science and Biotechnology Department (Voucher Number: UNH/027-University of Nigeria Herbarium/027). The leaf was separated from the stem and washed thoroughly with distilled water to remove debris. The dried pulverized leaf $(1,486 \mathrm{~g})$ was concentrated in 3.5 litres of deionized water for 18 hours. The mixture was filtered using a muslin cloth and further filtered with Whatmann No 1 filter paper. The mixture was evaporated to dryness LEICA RM 2125 RTS rotary microtone. 204.18g of the extract was obtained after evaporation with a percentage yield of $13.74 \%$ (McCloud, 2010). The extract was stored in a refrigerator for later use.

\subsection{Experimental Design}

The experimental animals were randomly distributed into four groups of six rats per triplicate. Group 1 served as control and was orally administered normal deionized water at a dose of $1 \mathrm{ml} / \mathrm{kg}$ body weight. Group 2, 3, and 4 were administered with aqueous leaf extract of Terminalia catappa (ALETA) at 150, 300, and 450mg/kg, respectively by oral gavage for 3 weeks. The dosages administered were obtained after zero mortality record of the acute toxicity test following the protocol of Lorke (1983). Meanwhile, the animals were immobilized using chloroform to obtain 3 tissues (liver, heart, and kidney) from 3 rats per group for histological examinations at the end of the experiment which lasted for three weeks.

\subsection{Phytochemical Screening of the Plant Material}

The analysis of the extract (flavonoids, tannins, saponins, alkaloids, steroids) was done following the standard methods of Trease and Evans, (2002).

\subsection{Histological Examination}

The histological analyses of the tissues (liver, kidney, and heart) were done according to the method of Akilandeswarietal, 2010).

\subsection{Haematological Parameters}

The blood haematocrit was determined by stuffing capillary tube with blood and centrifuged in a microheamatocrit (Hawksley England) at 14,000 Xg rpm for 5 minutes, and the percentage of the erythrocyte layers was evaluated and read using a heamatocrit reader (Wintrobe, 1967). The erythrocytes and leucocyte count were determined manually utilizing heamocytometer under X40 magnification. The concentration of haemoglobin in the blood was estimated using spectrophotometry combined with cyanmethaemoglobin method using Drabkins reagents (Wintrobe, 1967). The erythrocytes, packed cell volume, and haemoglobin were used in estimating the erythrocytes derivatives such as mean cell volume (MCV in fentolitres), mean cell haemoglobin (MCH in picogram) and mean cell haemoglobin concentration (MCHC in grams decilitre). Blood smears were obtained and stained with a may-Grunwald-Giemsa solution for accurate determination of differential leucocyte subpopulations.

\subsection{Biochemical Parameters}

Plasma levels of aspartate aminotransferase (AST) and Alanine aminotransferase (ALT) were assayed following the protocol of Reitman and Frankel, (1957). Acid and alkaline phosphatase enzymatic activity was determined following the protocol of Babson and Read (1959) and Bergmeyer, (1974), respectively.

\subsection{Data analysis}

The haematology and liver enzyme data were analyzed for significant differences $(\mathrm{p}<0.05)$ using analysis of variance (ANOVA). Also, differences between means were partitioned using the Duncan Multiple Range test (DNMRT). All analyses were done using Statistical Package for Social Sciences windows version 20.0 (IBM Corporation, Armonk, USA).

\section{Phytochemicals}

The phytochemical components of the aqueous leaf extract of Terminalia catappa were shown in Table 1. Meanwhile, the presence of alkaloids, terpenoids, saponins, tannins, and flavonoids was observed. The concentrations of the chemical constituents were similar. 
Table 1. Phytochemical constituents of aqueous leaf extract of

\begin{tabular}{lll}
\hline Phytochemical constituents & Bioavailability & Concentration (\%) \\
\hline Tannins & + & $0.32 \pm 0.00$ \\
Saponins & + & $0.48 \pm 0.01$ \\
Alkaloids & + & $0.37 \pm 0.00$ \\
Steroids & - & $0.03 \pm 0.00$ \\
Flavonoids & ++ & $1.68 \pm 0.14$ \\
\hline
\end{tabular}

3.1. Histological Changes in some tissues of Albino Rats Exposed to Aqueous Leaf Extracts of Terminalia catappa

The histological patterns of the normal liver revealed clearly defined parenchyma cells, central veins, sinusoids, and kupfer cells. Cytoplasmic vacuolations and kupfer cell hyperplasia were observed in the liver of albino rats exposed to $150 \mathrm{mg} / \mathrm{kg}$ ALETA. The enlarged sinusoid was filled with mixed infilterate. The clogged sinusoid observed in the liver of albino rats exposed to $300 \mathrm{mg} / \mathrm{kg}$ impeded the functions of the kupfer cells and allowed spent erythrocyte to build up in the blood instead of being removed, (Plate 1A). Further observations such as the influx of mononuclear cells in the dilated sinusoid were obvious, while the kupfer cells lined at the basement of the sinusoid phagocytized and removed spent erythrocytes and other particulate debris from circulating in the blood vessel of the liver tissue (Plate 1D). Moreso, cytoplasmic vacuolation associated with cells adaptively altered to resist further degeneration was observed. This also reflected a cellular adaptation beneficial to the host.
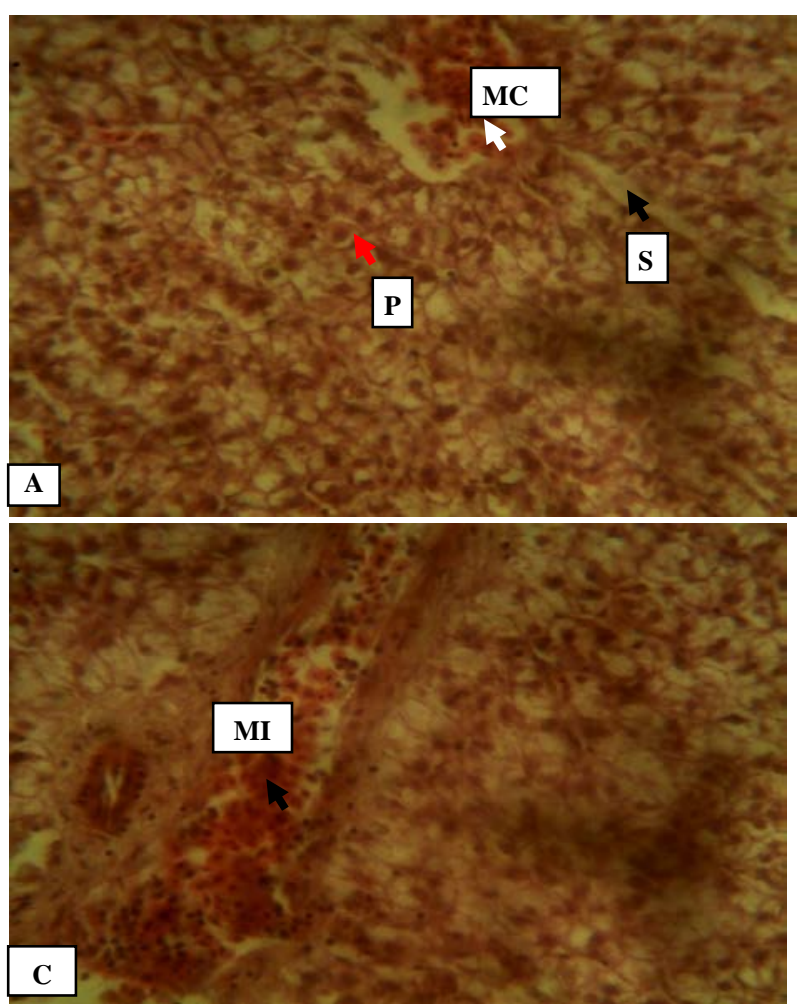
Terminalia catappa

-, absent + , present ++ moderately present

The histological patterns of the kidney shown in (Plate 2A) revealed normal renal corpuscles with intact glomerulus and epithelial cells linked to the tubules and connected with a tight junction that prevents waste products and other potentially harmful substances from passing between the cells and reaching the bloodstream. Some of the glomeruli structure appeared shrunk and vacuolated with discrete clear or translucent spaces observed in the kidney of albio rat administered $150 \mathrm{mg} / \mathrm{kg}$ (Plate 2B) and 300mg/kg ALETA (Plate 2C), respectively. Renal corpuscles were also intact in the group treated with $450 \mathrm{mg} / \mathrm{kg}$ ALETA (Plate 2D).

The histological patterns of the normal heart of albino rats showed prominent branching in the cardiac muscle fibre (Plate 3A). Myocardial fibre variations and blood vessels were observed in the heart of the albino rats exposed to $150 \mathrm{mg} / \mathrm{kg}$ of ALETA (Plate 3B), while at $300 \mathrm{mg} / \mathrm{kg}$ (Plate 3C) and 450mg/kg ALETA (Plate 3D), heart architecture showed normal branching of anastomosing intercalated disc with each other in a network pattern.

The stomach histological section of the normal control revealed intact muscularis mucosa and lamina propria of the stomach architecture (Plate 4A). Hemorrhage was observed in the fundic region of the stomach. Meanwhile, hemorrhage was observed in the blood vessels of the stomach following $150 \mathrm{mg} / \mathrm{kg}$ ALETA administration (Plate 4B). More so, at $300 \mathrm{mg} / \mathrm{kg}$ and $450 \mathrm{mg} / \mathrm{kg}$ ALETA (Plate $4 C$, and D), vascular congestion and degeneration of the inner circular layer such as degenerated muscularis mucosa were similarly observed, respectively.
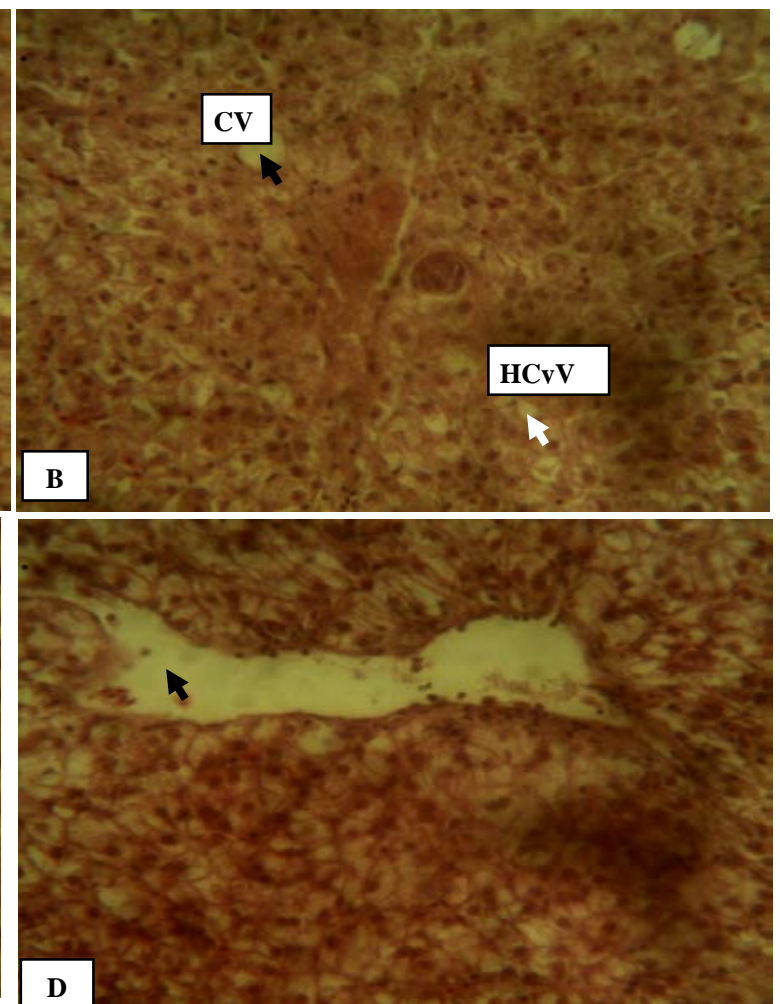

Plate 1: Photomicrograph of liver (A). normal parenchymal cells (PC) (red arrow), intact sinusoids (black arrow) and central vein infilterated with mononuclear cells (MC) (white arrow). Plate B. 150mg/kg of ALETA showing central vein (CV, black arrow), hepatocyte cytoplasmic vacuolation (HCyV, white arrow). Plate C: $300 \mathrm{mg} / \mathrm{kg}$ of ALETA showing mixed infilterate (MI) in the sinusoid (black arrow). Plate D: $450 \mathrm{mg} / \mathrm{kg}$ of ALETA showing enlarged sinusoids with few mononuclear cells (black arrow). H\&E. mag. 400X. 

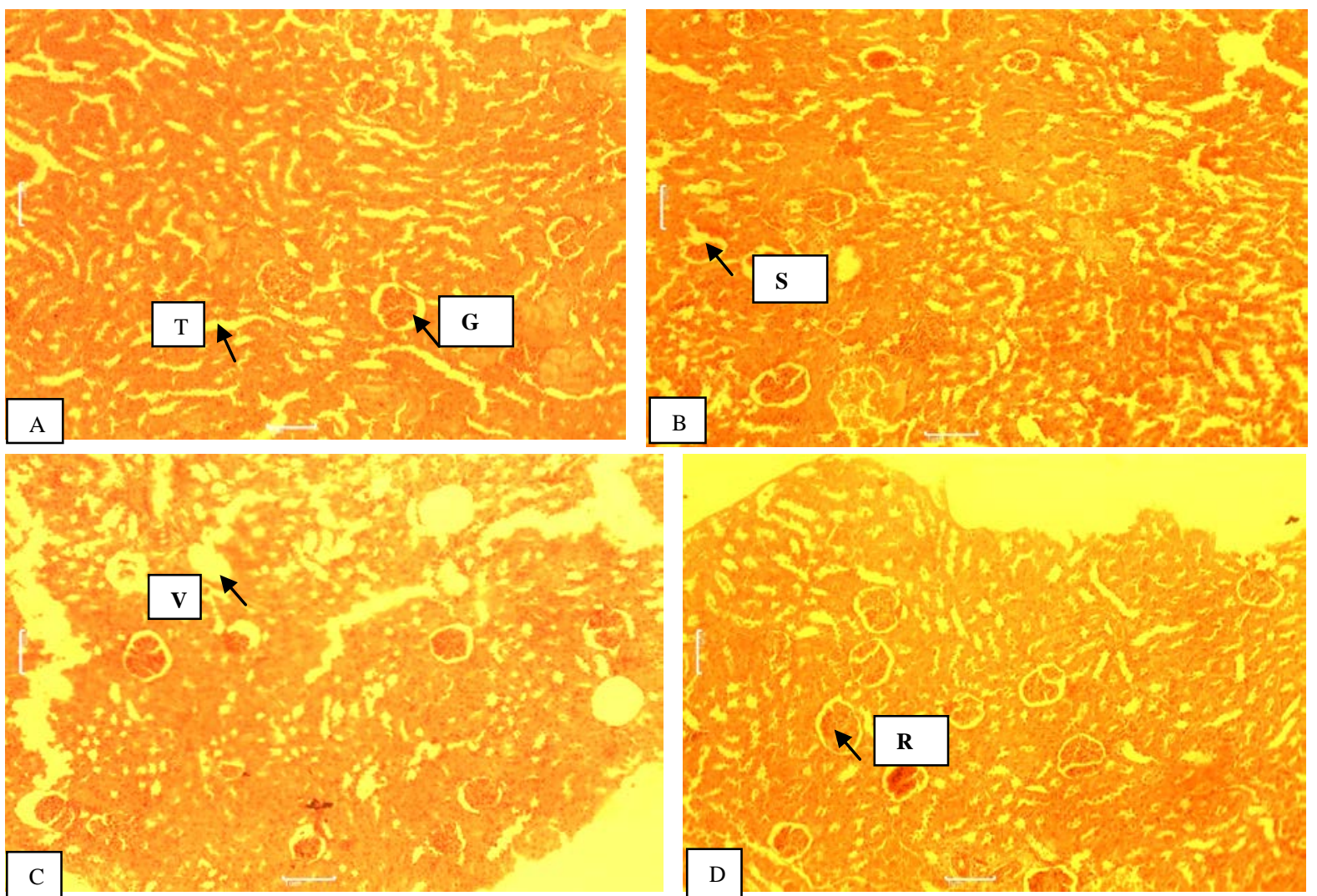

Plate 2: Photomicrograph of kidney of albino rats A: Normal group showing, normal renal corpuscles with intact glomerulus (GL) and tubules (T) lined with epithelial cells connected to each other in the kidney cortex. B: 150mg/kg of ALETA showing shrinkage of the glomeruli (SG black arrow). C:300mg/kg ALETA showing kidney vacuolation (V black arrow) was observed. D: 450mg/kg ALETA, with intact renal corpuscules (RC). H\&E. mag. 100X.

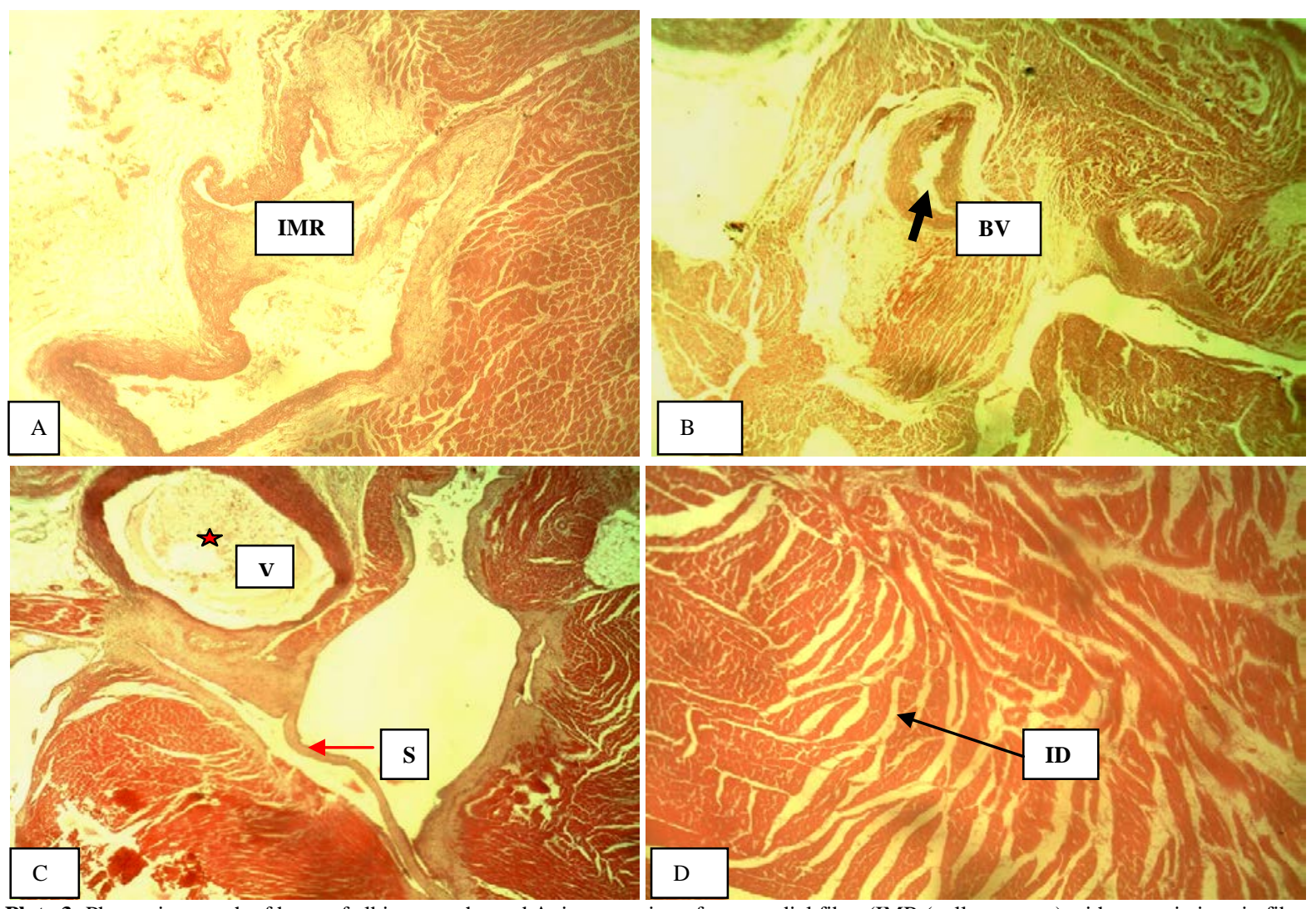

Plate 3: Photomicrograph of heart of albino rats showed A. intact region of myocardial fibre (IMR (yellow arrow) with no variations in fibre sizes. B. $150 \mathrm{mg} / \mathrm{kg}$ of ALETA showing no myocardial fibre variation and intact blood vessels (BV black arrow). Plate C. 300 $\mathrm{mg} / \mathrm{kg}$ of ALETA showing normal heart architecture, intact valve (red star), and septum (red arrow). Plate D. 450mg/kg of ALETA showing rominent cardiac region of the heart with intact intercalated disc (ID). H\&E. mag. 100X. 

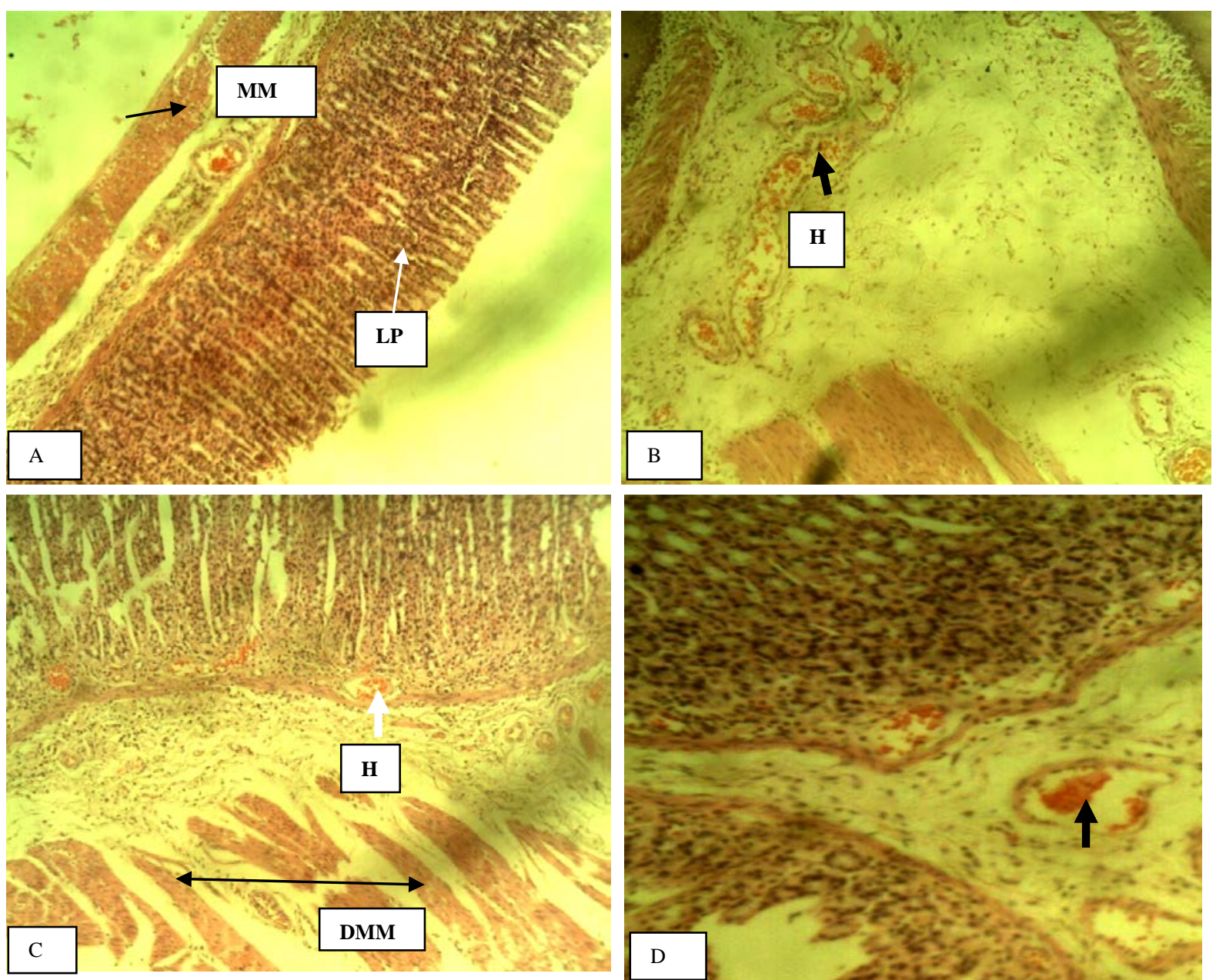

Plate 4. Photomicrograph of stomach of albino rats A. Normal group with intact stomach architecture characterized by muscularis mucosa (MM black arrow) and lamina propria (LP) (white arrow). B. 150mg/kg of ALETA with revealed hemorrhage (black arrow) mainly in blood vessels which occurred on the mucosal region of the stomach. C: $300 \mathrm{mg} / \mathrm{kg}$ of ALETA with degenerated muscularis mucosa (DMM black arrow), minor hemorrhage (white arrow), blood vessel congestion and degeneration of the inner circular layer. D. 450 mg/kg of ALETA with revealed thickness of the muscularis mucosa, minor vascular congestion (black arrow) H\&E. mag. 100X.

\subsection{Effects of Terminaliacatappaon Haematological Parameters of animals}

The haematological parameters PCV, RBC, HB, and WBC were affected by $T$. catappa treatment. The response of these parameters was mainly dose-dependent. The duration of treatment significantly affected RBC $(\mathrm{F}=$ 8.149, $\mathrm{p}<0.0001)$. PCV was not different between the groups except on week 2 where PCV was significantly higher in $450 \mathrm{mg} / \mathrm{kg}$ extract group compared to others. Hb concentration was similarly different between the groups. Those treated with $450 \mathrm{mg} / \mathrm{kg}$ extract had the highest $\mathrm{Hb}$ level. WBC was not different between the groups and did not change significantly for the duration of treatment with $T$. catappa (Table 1). White blood cell differential to $T$. catappa responses are summarized in Table 2. No consistent response of neutrophil, eosinophil, and monocytes to the extract treatment was observed, irrespective of the concentrations used. Lymphocytes, however, appeared to increase in concentration with increasing doses of extract. The concentration of lymphocyte at $450 \mathrm{mg} / \mathrm{kg}$ and $300 \mathrm{mg} / \mathrm{kg}$ was significantly higher compared to control on weeks 2 and 3 . The red blood cell derivatives, MCV, MCH, and MCHC responded minimally to T. catappa treatment. Overall, only MCV (F $=3.857, \mathrm{p}=0.018)$ and $\mathrm{MCH}(\mathrm{F}=5.869, \mathrm{p}=0.003)$ were significantly affected by the duration of treatment, while only $\mathrm{MCH}(\mathrm{F}=3.232, \mathrm{p}=0.035)$ was affected significantly by the extract. A significant increase in $\mathrm{MCH}$ relative to control, was observed on week 2 at $450 \mathrm{mg} / \mathrm{kg}$ extract (Table 3). 
Table 2. Haematological changes in animals treated with Terminalia catappa

\begin{tabular}{|c|c|c|c|c|c|}
\hline \multirow[t]{2}{*}{ Parameter } & \multirow{2}{*}{$\begin{array}{l}\text { Concentration. } \\
(\mathrm{mg} / \mathrm{kg})\end{array}$} & \multicolumn{4}{|l|}{ Duration (week) } \\
\hline & & 0 & 1 & 2 & 3 \\
\hline \multirow[t]{5}{*}{ PCV(\%) } & Control & $24.67 \pm 1.15^{\mathrm{a} 2}$ & $26.67 \pm 1.53^{\mathrm{a} 2}$ & $19.00 \pm 2.00^{\mathrm{b} 1}$ & $27.66 \pm 2.52^{\mathrm{a} 2}$ \\
\hline & 150 & $24.33 \pm 5.51^{\mathrm{a} 1}$ & $22.00 \pm 2.65^{\mathrm{a} 1}$ & $21.66 \pm 3.51^{\mathrm{b} 1}$ & $23.00 \pm 3.61^{\mathrm{a} 1}$ \\
\hline & 300 & $26.67 \pm 4.93^{\mathrm{a} 1}$ & $27.67 \pm 2.89^{\mathrm{a} 1}$ & $20.33 \pm 1.53^{\mathrm{b} 1}$ & $22.33 \pm 4.73^{\mathrm{a} 1}$ \\
\hline & 450 & $27.33 \pm 6.11^{\mathrm{a} 1}$ & $27.00 \pm 1.73^{\mathrm{a} 1}$ & $31.66 \pm 2.52^{\mathrm{a} 1}$ & $29.33 \pm 4.51^{\mathrm{a} 1}$ \\
\hline & Control & $118.0 \pm 7.55^{\mathrm{a} 1}$ & $121.0 \pm 4.36^{\mathrm{a} 1}$ & $104.6 \pm 15.5^{\mathrm{a} 1}$ & $120.6 \pm 12.1^{\mathrm{a} 1}$ \\
\hline \multirow[t]{3}{*}{$\mathrm{RBC}\left(\mathrm{X} 10^{6}\right)$} & 150 & $83.33 \pm 1.53^{\mathrm{b} 1}$ & $120.6 \pm 9.6^{\mathrm{a} 2}$ & $96.00 \pm 11.0^{\mathrm{a} 1}$ & $84.00 \pm 5.57^{\mathrm{b} 1}$ \\
\hline & 300 & $97.00 \pm 7.00^{\mathrm{b} 1}$ & $131.3 \pm 15.5^{\mathrm{a} 2}$ & $98.33 \pm 5.51^{\mathrm{a} 1}$ & $94.33 \pm 16.2^{\mathrm{b} 1}$ \\
\hline & 450 & $134.0 \pm 11.1^{\mathrm{a} 1}$ & $124.3 \pm 6.81^{\mathrm{a} 1}$ & $135.3 \pm 7.09^{\mathrm{b} 1}$ & $131.3 \pm 7.02^{\mathrm{a} 1}$ \\
\hline \multirow[t]{4}{*}{$\mathrm{HB}(\mathrm{g} / \mathrm{dl})$} & Control & $8.233 \pm 0.40^{\mathrm{ab} 2}$ & $8.867 \pm 0.51^{\mathrm{a} 2}$ & $6.333 \pm 0.65^{\mathrm{b} 1}$ & $9.220 \pm 0.84^{\mathrm{ab} 2}$ \\
\hline & 150 & $8.100 \pm 1.82^{\mathrm{ab} 1}$ & $7.333 \pm 0.91^{\mathrm{a} 1}$ & $7.200 \pm 1.15^{\mathrm{a} 1}$ & $6.566 \pm 0.81^{\mathrm{b} 1}$ \\
\hline & 300 & $7.000 \pm 0.30^{\mathrm{b} 12}$ & $9.233 \pm 0.92^{\mathrm{a} 2}$ & $6.767 \pm 0.50^{\mathrm{a} 1}$ & $7.433 \pm 1.53^{\mathrm{b} 12}$ \\
\hline & 450 & $16.57 \pm 0.80^{\mathrm{a} 1}$ & $8.967 \pm 0.58^{\mathrm{a} 1}$ & $10.57 \pm 0.81^{\mathrm{a} 1}$ & $11.20 \pm 1.55^{\mathrm{a} 1}$ \\
\hline \multirow[t]{4}{*}{ WBC $\left(\times 10^{3}\right)$} & Control & $14733.33 \pm 2362.90^{\mathrm{a} 2}$ & $11266.66 \pm 1040.83^{\mathrm{a} 2}$ & $14766.66 \pm 750.56^{\mathrm{a} 2}$ & $9800.00 \pm 1228.82^{\mathrm{a} 1}$ \\
\hline & 150 & $1400.00 \pm 3019.93^{\mathrm{a} 1}$ & $14533.33 \pm 3744.77^{\mathrm{a} 1}$ & $12633.33 \pm 1755.94^{\mathrm{a} 1}$ & $14100.00 \pm 854.40^{\mathrm{a} 1}$ \\
\hline & 300 & $1340.00 \pm 3019.93^{\mathrm{a} 1}$ & $12900.00 \pm 624.50^{\mathrm{a} 1}$ & $12300.00 \pm 1228.82^{\mathrm{a} 1}$ & $15000.00 \pm 4293.02^{\mathrm{a} 1}$ \\
\hline & 450 & $11666.66 \pm 378.60^{\mathrm{a} 1}$ & $12166.66 \pm 4539.0^{\mathrm{a} 1}$ & $13000.00 \pm 1900.00^{\mathrm{a} 1}$ & $13800.00 \pm 1400.00^{\mathrm{a} 1}$ \\
\hline
\end{tabular}

Values as mean \pm standard deviation. Values with different alphabet superscript along a column were significantly different, while values with different numeric superscript across a row were significantly different $(\mathrm{p}<0.05)$

Table 3. White blood cell differential (\%) of animals treated with Terminalia catappa extract

\begin{tabular}{|c|c|c|c|c|c|}
\hline \multirow[b]{2}{*}{ Parameters } & \multirow[t]{2}{*}{ Conc. (mg/kg) } & \multicolumn{4}{|c|}{ Duration (week) } \\
\hline & & 0 & 1 & 2 & 3 \\
\hline \multirow[t]{4}{*}{ Neutrophil } & Control & $66.67 \pm 3.79^{\mathrm{b3}}$ & $18.67 \pm 2.08^{\mathrm{a} 1}$ & $43.00 \pm 4.00^{\mathrm{a} 2}$ & $14.67 \pm 1.53^{\mathrm{ab} 1}$ \\
\hline & 150 & $71.67 \pm 4.73^{\mathrm{ab} 3}$ & $23.00 \pm 2.00^{\mathrm{a} 1}$ & $42.00 \pm 3.40^{\mathrm{a} 2}$ & $22.67 \pm 4.04^{\mathrm{a} 1}$ \\
\hline & 300 & $71.67 \pm 3.79^{\mathrm{ab} 3}$ & $18.33 \pm 2.08^{\mathrm{a} 12}$ & $26.33 \pm 4.51^{\mathrm{b} 2}$ & $16.00 \pm 5.30^{\mathrm{ab} 1}$ \\
\hline & 450 & $77.67 \pm 1.53^{\mathrm{a} 3}$ & $19.67 \pm 4.62^{\mathrm{a} 2}$ & $11.00 \pm 1.00^{\mathrm{c} 1}$ & $11.00 \pm 1.00^{\mathrm{a} 1}$ \\
\hline \multirow[t]{4}{*}{ Eosinophil } & Control & $2.000 \pm 1.13^{\mathrm{a} 1}$ & $1.333 \pm 0.58^{\mathrm{a} 1}$ & $0.000 \pm 0.00^{\mathrm{b} 1}$ & $1.667 \pm 1.53^{\mathrm{a} 1}$ \\
\hline & 150 & $1.667 \pm 0.58^{\mathrm{a} 1}$ & $0.667 \pm 0,58^{\mathrm{a} 1}$ & $0.000 \pm 0.00^{\mathrm{b} 1}$ & $1.000 \pm 1.000^{\mathrm{a} 1}$ \\
\hline & 300 & $2.000 \pm 1.00^{\mathrm{a} 1}$ & $1.00 \pm 1.00^{\mathrm{a} 1}$ & $2.000 \pm 1.00^{\mathrm{a} 1}$ & $0.667 \pm 1.15^{\mathrm{a} 1}$ \\
\hline & 450 & $0.00 \pm 0.00^{\mathrm{a} 1}$ & $6.667 \pm 0.58^{\mathrm{a} 1}$ & $0.000 \pm 0.00^{\mathrm{b} 1}$ & $0.667 \pm 1.15^{\mathrm{a} 1}$ \\
\hline \multirow[t]{4}{*}{ Monocytes } & Control & $7.67 \pm 2.52^{\mathrm{a} 1}$ & $6.667 \pm 2.53^{\mathrm{a} 1}$ & $11.33 \pm 1.53^{\mathrm{ab} 1}$ & $8.667 \pm 2.89^{\mathrm{a} 1}$ \\
\hline & 150 & $6.67 \pm 2.31^{\mathrm{a} 1}$ & $6.000 \pm 2.65^{\mathrm{a} 1}$ & $14.00 \pm 3.00^{\mathrm{a} 1}$ & $11.000 \pm 4.36^{\mathrm{a} 1}$ \\
\hline & 300 & $7.00 \pm 2.00^{\mathrm{a} 1}$ & $7.667 \pm 2.89^{\mathrm{a} 1}$ & $7.000 \pm 2.00^{\mathrm{b} 1}$ & $11.333 \pm 2.52^{\mathrm{a} 1}$ \\
\hline & 450 & $3.67 \pm 3.06^{\mathrm{a} 1}$ & $6.000 \pm 1.73^{\mathrm{a} 1}$ & $7.000 \pm 1.00^{\mathrm{b} 1}$ & $7.333 \pm 1.53^{\mathrm{a} 1}$ \\
\hline \multirow[t]{4}{*}{ Lymphocytes } & Control & $23.00 \pm 4.00^{\mathrm{a} 1}$ & $60.67 \pm 25.81^{\mathrm{a} 2}$ & $45.67 \pm 3.21^{\mathrm{c} 12}$ & $75.000 \pm 2.00^{\mathrm{ab} 2}$ \\
\hline & 150 & $20.00 \pm 2.00^{\mathrm{a} 1}$ & $70.33 \pm 1.53^{\mathrm{a} 3}$ & $44.00 \pm 1.73^{\mathrm{c} 2}$ & $69.33 \pm 6.11^{\mathrm{b} 3}$ \\
\hline & 300 & $19.33 \pm 1.15^{\mathrm{a} 1}$ & $73.000 \pm 1.00^{\mathrm{a} 2}$ & $64.67 \pm 5.03^{\mathrm{b} 2}$ & $72.00 \pm 4.60^{\mathrm{ab} 2}$ \\
\hline & 450 & $18.67 \pm 1.53^{\mathrm{a} 1}$ & $73.67 \pm 6.66^{\mathrm{a} 2}$ & $82.000 \pm 1.73^{\mathrm{a} 2}$ & $81.00 \pm 0.00^{\mathrm{a} 2}$ \\
\hline
\end{tabular}

Values as mean \pm standard deviation. Values with different alphabet superscript along a column were significantly different, while values with different numeric superscript across a row were significantly different $(\mathrm{p}<0.05)$.

Table 4. Red blood cell derivatives of animals treated with Terminalia catappa

\begin{tabular}{|c|c|c|c|c|c|}
\hline \multirow[t]{2}{*}{ Parameter } & \multirow{2}{*}{$\begin{array}{l}\text { Conc. } \\
\text { (mg/kg) }\end{array}$} & \multicolumn{4}{|c|}{ Duration (week) } \\
\hline & & 0 & 1 & 2 & 3 \\
\hline \multirow[t]{5}{*}{ MCV (fl cell ${ }^{-1}$ ) } & Control & $2.093 \pm 0.08^{\mathrm{a} 2}$ & $2.20 \pm 0.06^{\mathrm{a} 2}$ & $1.83 \pm 0.17^{\mathrm{b} 1}$ & $2.29 \pm 0.02^{\mathrm{a} 2}$ \\
\hline & 150 & $2.919 \pm 0.06^{\mathrm{a} 1}$ & $1.84 \pm 0.33^{\mathrm{a} 1}$ & $2.25 \pm 0.12 \mathrm{a} 1$ & $2.76 \pm 0.06^{\mathrm{a} 1}$ \\
\hline & 300 & $2.771 \pm 0.06^{\mathrm{a} 1}$ & $2.11 \pm 0.50^{\mathrm{a} 1}$ & $2.07 \pm 0.11^{\mathrm{ab} 1}$ & $2.36 \pm 0.13^{\mathrm{a} 1}$ \\
\hline & 450 & $2.073 \pm 0.06^{\mathrm{a} 1}$ & $2.17 \pm 0.16^{\mathrm{a} 1}$ & $2.34 \pm 0.08^{\mathrm{b} 1}$ & $2.23 \pm 0.30^{\mathrm{a} 1}$ \\
\hline & Control & $0.6985 \pm 0.03^{\mathrm{a} 2}$ & $0.73 \pm 0.021^{\mathrm{a} 2}$ & $0.61 \pm 0.06^{\mathrm{b} 1}$ & $0.76 \pm 0.01^{\mathrm{a} 2}$ \\
\hline \multirow[t]{4}{*}{ MCH(pg cell $\left.{ }^{-1}\right)$} & 150 & $0.972 \pm 0.22^{\mathrm{a} 2}$ & $0.61 \pm 0.011^{\mathrm{a} 1}$ & $0.75 \pm 0.04^{\mathrm{a} 12}$ & $0.78 \pm 0.05^{\mathrm{a} 12}$ \\
\hline & 300 & $0.723 \pm 0.03^{\mathrm{a} 12}$ & $0.70 \pm 0.018^{\mathrm{a} 1}$ & $0.69 \pm 0.03^{\mathrm{ab} 1}$ & $0.78 \pm 0.04^{\mathrm{a} 2}$ \\
\hline & 450 & $0.789 \pm 0.02^{\mathrm{a} 1}$ & $0.72 \pm 0053^{\mathrm{a} 1}$ & $0.78 \pm 0.03^{\mathrm{a} 1}$ & $0.86 \pm 0.16^{\mathrm{a} 1}$ \\
\hline & Control & $33.38 \pm 0.07^{\mathrm{a} 1}$ & $33.25 \pm 0.07^{\mathrm{a} 1}$ & $33.34 \pm 0.19^{\mathrm{a} 1}$ & $33.32 \pm 0.01^{\mathrm{a} 1}$ \\
\hline \multirow[t]{3}{*}{ MCHC g/dl) } & 150 & $33.30 \pm 0.07^{\mathrm{a} 1}$ & $33.32 \pm 0.16^{\mathrm{a} 1}$ & $33.24 \pm 0.08^{\mathrm{a} 1}$ & $29.26 \pm 7.06^{\mathrm{a} 1}$ \\
\hline & 300 & $26.95 \pm 5.71^{\mathrm{a} 1}$ & $33.38 \pm 0.01^{\mathrm{a} 1}$ & $33.28 \pm 0.19^{\mathrm{a} 1}$ & $33.31 \pm 0.23^{\mathrm{a} 1}$ \\
\hline & 450 & $40.35 \pm 11.4^{\mathrm{a} 1}$ & $33.21 \pm 0.01^{\mathrm{a} 1}$ & $33.37 \pm 0.12^{\mathrm{a} 1}$ & $39.05 \pm 10.18^{\mathrm{a} 1}$ \\
\hline
\end{tabular}

Values as mean \pm standard deviation. Values with different alphabet superscript along a column were significantly different, while values with different numeric superscript across a row were significantly different $(\mathrm{p}<0.05)$. 


\subsection{Effects of Terminalia catappa on} Biochemicalparameters of animals

The changes in the liver enzyme of albino rats exposed to ALETA are shown in Table 5. The level of AST, ALT, ALP, and ACP in the ALETA exposed rats did not differ significantly $(\mathrm{p}>0.05)$ at the end of the experiment. Overall, all the biochemical parameters investigated were not affected significantly by the extract.

Table 5. Changes in the liver enzymes of animals treated with Terminalia catappa

\begin{tabular}{|c|c|c|c|c|}
\hline \multirow{2}{*}{ Parameter } & \multirow{2}{*}{$\begin{array}{l}\text { Conc. } \\
\text { (mg/kg) }\end{array}$} & \multicolumn{3}{|c|}{ Duration (week) } \\
\hline & & 1 & 2 & 3 \\
\hline \multirow{4}{*}{$\begin{array}{l}\text { AST } \\
(\mathrm{U} / \mathrm{L})\end{array}$} & Control & $43.67 \pm 4.16^{\mathrm{c} 1}$ & $36.67 \pm 1.16^{\mathrm{b} 1}$ & $39.00 \pm 3.00^{\mathrm{a} 1}$ \\
\hline & 150 & $71.33 \pm 3.51^{\mathrm{a} 1}$ & $70.67 \pm 3.06^{\mathrm{a} 1}$ & $73.00 \pm 10.58^{\mathrm{a} 1}$ \\
\hline & 300 & $60.00 \pm 6.25^{\mathrm{b} 1}$ & $76.33 \pm 11.15^{\mathrm{a} 1}$ & $72.67 \pm 6.11^{\mathrm{a} 1}$ \\
\hline & 450 & $63.33 \pm 2.89^{\mathrm{ab} 1}$ & $74.67 \pm 6.03^{\mathrm{a} 1}$ & $62.33 \pm 7.37^{\mathrm{a} 1}$ \\
\hline \multirow{4}{*}{$\begin{array}{l}\text { ALT } \\
(\mathrm{U} / \mathrm{L})\end{array}$} & Control & $42.00 \pm 3.61^{\mathrm{b} 1}$ & $42.67 \pm 9.29^{\mathrm{b} 1}$ & $41.67 \pm 5.51^{\mathrm{a} 1}$ \\
\hline & 150 & $60.67 \pm 5,86^{\mathrm{a} 1}$ & $61.00 \pm 3.61^{\mathrm{ab} 1}$ & $61.33 \pm 9.45^{\mathrm{a} 1}$ \\
\hline & 300 & $75.67 \pm 6.03^{\mathrm{a} 1}$ & $72.00 \pm 9.64^{\mathrm{a} 1}$ & $59.67 \pm 6.11^{\mathrm{a} 1}$ \\
\hline & 450 & $61.00 \pm 10.15^{\mathrm{a} 1}$ & $49.33 \pm 5.69^{\mathrm{b} 1}$ & $65.33 \pm 15.18^{\mathrm{a} 1}$ \\
\hline \multirow{4}{*}{$\begin{array}{l}\text { ACP } \\
(\mathrm{U} / \mathrm{L})\end{array}$} & Control & $20.59 \pm 0.72^{\mathrm{a} 1}$ & $22.99 \pm 0.64^{\mathrm{a} 1}$ & $23.36 \pm 2.68^{\mathrm{a} 1}$ \\
\hline & 150 & $24.28 \pm 1.66^{\mathrm{a} 1}$ & $30.64 \pm 4.87^{\mathrm{a} 1}$ & $24.43 \pm 3.33^{\mathrm{a} 1}$ \\
\hline & 300 & $24.00 \pm 3.04^{\mathrm{a} 1}$ & $28.42 \pm 0.82^{\mathrm{a} 1}$ & $24.54 \pm 2.07^{\mathrm{a} 1}$ \\
\hline & 450 & $21.29 \pm 1.12^{\mathrm{a} 1}$ & $25.75 \pm 3.15^{\mathrm{a} 1}$ & $27.68 \pm 3.17^{\mathrm{a} 1}$ \\
\hline \multirow{4}{*}{$\begin{array}{l}\text { ALP } \\
(\mathrm{U} / \mathrm{L})\end{array}$} & Control & $24.31 \pm 18.15^{\mathrm{a} 1}$ & $38.28 \pm 1.54^{\mathrm{b} 1}$ & $33.73 \pm 2.08^{\mathrm{a} 1}$ \\
\hline & 150 & $40.44 \pm 7.69^{\mathrm{a} 1}$ & $43.22 \pm 4.64^{\mathrm{a} 1}$ & $36.63 \pm 5.08^{\mathrm{a} 1}$ \\
\hline & 300 & $37.08 \pm 1.90^{\mathrm{a} 1}$ & $45.21 \pm 4.66^{\mathrm{a} 2}$ & $33.54 \pm 1,15^{\mathrm{a} 1}$ \\
\hline & 450 & $37.76 \pm 4.14^{\mathrm{a} 1}$ & $33.01 \pm 2.39^{\mathrm{b} 1}$ & $35.65 \pm 2.16^{\mathrm{a} 1}$ \\
\hline
\end{tabular}

Values as mean \pm standard deviation. Values with different alphabet superscript along a column were significantly different, while values with different numeric superscript across a row were significantly different $(\mathrm{p}<0.05)$.

\section{Discussion}

Physiological and nutritional observations (Azrul et al., 2013) have shown that Terminalia catappa has the potential to induce primary toxicity in rats. The phytochemical constituents (alkaloids, flavonoids etc.) of the ALETA reported in the current study are in consonance with those observed by previous investigators (Divya et al, 2018, Divya and Vijya-Anand, 2014). The histopathology alterations in the liver against highest dosage of ALETA presented minor clear liver alterations such as Kupfer cell hyperplasia, cytoplasmic vacuolation, necrosis, and sinusoid enlargement. However, the observations in the kidney suggested that ALETA had a renal protective ability to prevent kidney dysfunction by accelerating regeneration. Alade et al (2009) opined that $4 \mathrm{~g} / \mathrm{kg}$ Baulinia monandra leaf extract caused focal prominent tubular epithelial necrosis in the kidney. Further studies reported widened glomeruli of the kidney exposed to $1000 \mathrm{mg} / \mathrm{kg}$ Cassia fistula. This coincided with the changes in the kidney of rats exposed to 150, 300, and $450 \mathrm{mg} / \mathrm{kg}$ ALETA observed with shrinkage of glomeruli, discrete clear or translucent space associated with vacuolations was reported in the present study. No damage was observed in the heart histology. This was due to possible cardioprotective potentials of ALETA administered between 150 to $450 \mathrm{mg} / \mathrm{kg}$ in the study. Observed vascular and minor lesions, in the fundic stomach of albino rats exposed to different dosages of the ALETA, were due to intoxication of the extracts.

Blood parameters are used to ascertain the physiological effects of foreign compounds, including medicinal plants. The current study revealed significant activity of the plant extract on RBC, PCV, HB, N, E, M, L, $\mathrm{MCH}$, and MCHC, does not affect erythropoiesis and osmotic fragility of the red blood cells. The white blood cells (WBC) are the first line of defense which responds to infectious agents, inflammatory process, or tissue injury. The increased WBC level in the blood cells of wistar rats observed in the current study was due to stimulation of production of leucocytes by Terminalia catappa as immune booster. On the contrary, Ezekiel et al, (2019) reported decreased WBC level in wistar rats exposed to Termialia catappa leaf extract. More so, there were no significant changes observed in the neutrophils, lymphocytes, and monocytes in Terminalia catappa leaf extract-treated animals. The Hb levels made T. catappa a positive herb for blood building. $450 \mathrm{mg} / \mathrm{kg} T$ catappa decreased packed cell volume and erythrocyte count in albino rats (Ezekiel et al, 2019, Aimola et al, 2011). No significant change in the PCV was observed inT.catappa decoctions administered albino rats (Ibegbulem et al 2011). The increased MCHC values have been reported to be one of the conditions that precipitated disease conditions such as sickling Ibegbulem et al (2011). Erythrocytes derivatives were not altered after administration of T. catappa to albino rats (Ezekiel et al, 2019).

Liver enzymes are consistently utilized as an index of liver diagnosis, investigation of disease, and safety assessment of herbal plants (Madu and Nadro, 2017). The ALETA dosages caused liver damage with increased AST and ALT concentrations in the serum. Terminalia catappa plant extracts affected the level of aminotransferase enzymes (AST and ALT) in the serum supported by the limited degree of altered liver enzyme which indicated amelioration of hepatotoxic in the animal (Lin, 1997). Meanwhile, a two to four folds increase of liver enzymes raised concerns as an indication of potential hepatic injury Arjariya et al, (2013). The mechanism of action of the plant extracts prevented the intracellular release of enzyme and its membrane. Arjariya et al (2013) reported that the transaminases (AST and ALT) are well-known enzymes used as biomarkers predicting possible liver toxicity. This coincided with our present findings of elevated liver enzymes AST, ALT, ACP, ALP on chronic ingestion of ALETA. These observations may indicate that chronic ingestion of ALETA may result in potential hepatic injury/or compromised liver function.

\section{Conclusion}

The aqueous leaf extract of Termialia catappa has shown a significant effect on the tissues in the major body organs of rats that were investigated, with no toxicological effects observed in the heart of the animal. Therefore, the use of Terminalia catappa leaf as prophylaxis, nutriment, anti-inflammatory, etc., should be adopted with caution if 
it must be used, and serious review on the administration must be emphasized.

\section{Acknowledgment}

We acknowledge the Department of Zoology and Environmental Biology for their assistance in providing laboratory work space.

\section{Authors Contributions}

Chika B. Ikele (CBI). Designed the experiment, supervised the research, conducted and monitored the experiment, interpreted histological tissues, and proofread the manuscript. Elijah Okwuonu(EO), analyzed the research data. Nnachi A. Ijem (NAI) proofread the manuscript.

\section{Data Availability}

Research Data are not shared.

\section{Conflict of interest}

The authors declare no conflict of interests.

\section{References}

Ahmed SM, Vrushabendra SBM, Gopkumar RD and Chandrashekara VM. 2005. Anti-diabetic activity of Terminalia catappaLin- leaf extracts in alloxan-induced diabetic rats. Iranian J Pharm Therap, 4(1):36-39.http://ijpt.iums.ac.ir

Aimola S, Inuwa H, Mamman A, Habila N, Agbaji A and Omoniwa D. 2011. Terminalia catappa extract enhances erythropoiesis in adult Balb C Mice. JMol Bio Res, 1 : 40-46. Doi :10.5539/jmbr.v1n1p40

Akilandeswari S, Senthamarai R, Valarmarthi R, Shanthi S and Prema S. 2010. Screening of gastric antiulcer activity of Sidaacuta burm. Int J Pharmtech Res, 2:1644-1648.

AladeGO, Akanmu MA, Obuotor EM, Osasan SA and Omobuwajo AN. 2009. Acute and oral subacute toxicity of methanolic extract of Bauhinia monandra leaf in rats. Afri JPharm Pharmacol,3: 354-358.

http://www.academicjournals.org/ajpp

Alka D. Raman D. and Yogesh KS. 2016. Exploration of phytochemicals found in Terminalia $s p$ and their antiretroviral activities. PHARMACOGREV, 10: 73-83. Doi:10.4103/09737847.194048

Anand AV, Natarajan DP and Kotti PP. 2014. An updated review of Terminalia catappaPHARMACOGREV, 9: 93 - 98. Doi:10.4103/0973-7847.162103.

Arjariya S, Nema N and Tiwari S. 2013. Investigate the toxicological effect on aqueous extract of Terminalia catappaLin in rat. Int J Res Dev Pharm Life Sci,2: 596 - 601.

Azrul LM, Adeemi MA, Ahmad WM and Effendy AW. 2013. Determination of toxicological effects of Termianliacatappaleaf on Sprague-Dawley white rats in short period. IntJ Toxicol Applied Pharmacol, 3: 44 - 47.

Babson AL and Read AP. 1959. A colorimetric method for the determination of acidphosphatase enzyme. Am J ClinPath, 32: 89 $-91$

Bergmeyer HU. 1974. Methods of Enzymatic Analysis, $2^{\text {nd }}$ edition. Academic Press, New York.
Biswas M, Kar B, Bhattachyra S, Suresh-Kumar RB, Ghosh AK, Haldar PK. 2011. Antihyperglycemic activity and antioxidant role of Terminalia arjuna leaf in streptozotocin-induced diabetic rats. Pharma Biol, 49: 335-340.

https://doi.org/10.3109/13880209.2010.515755

Chu SC, Yang SF, Liu SJ, Kuw WH, Chang YZ and Hsei YS. 2007. Invitro and in vivo antimetastatic effects of Terminalia catappa L. leaf on lung cells. Food Chem Toxicol, 45:1197-1201. Doi:10.1016/j.fct.2006.12.028

Divya N and Vijya-Anand A. 2014. Phytochemical investigation and in vitro anti-diabetic activity of Terminalia catappaleaf. Int J Phyto Pharm, 4:132-134.

Divya N, Rengarajan, RL, Ramalingam, Elsayed, FA, Abdulaziz, AA, Abeer H, Manikandan R and Vijaya-Anand, A. 2018. Phytotherapeutic efficacy of the medicinal plant Terminaliacatappa L. Saudi J Biol Sci, 26: 985-988.. https:doi.org/10.1016/j.sjbs.2018.12.010

Ezekiel EB, Esther OAand Asuquo EA. 2019. Changes in heamatological parameters and possible adverse reactions of Terminalia catappaleaf extract in wister rats. J Nurs Health Sci, 8:80-86. www.iosrjournals.org.

Ibegbulem CO, Eyong EU. and Essien ET. (2011). Biochemical effects of drinking Terminalia catappaLin. decoction in Wistar rats Afri J Biochem Res5: 237 - 243.

Kinoshita S and Aniya Y. 2007. Antioxidant and hepatoprotective actions of medicinal herb, Terminalia catappa L. from Okinawa Island and its tannin corilagin, Phytomedi, 14: 755-762. Doi.org/10.1016/j.phymed.2006.12.012.

Koffi N, Bra Yvette F and Noel Z. 2011. Effect of aqueous extract of Terminalia catappaleaf on the glycaemia of rabbits. J Appl Pharmaceutical Sci; 1: 59 - 64. www.japsonline.com

Krishnaveni M. 2014. In vitro antioxidant activity of Terminalia catappa nuts. Asian J Pharmaceutic Clin Res, 7(4): 33-35.

Kumar V, Sharma N, Sourirajan A, Khosla KP and Dev K. 2018. Comparative evaluation of antimicrobial and antioxidant potential of ethanolic extract and its fraction of bark and leaf of Terminalia arjuna from North-Western Himalayas India. J Trad Compl Med, 8: 100-106. Doi:10.24896/eijppr.2016615

Lee CJ, Yang SF, Wang PH, Su CW, Hsu HF, Tsai, HT et al. 2019. Antimetastatic effects of Terminalia catappa leaf extracts on cervical cancer through the inhibitation of matrix metalloprotein-9 and MAPK pathway. Environ Toxicolo34:6066.https://doi.org/10.1002/tox.22657

Lin C, Chen Y, Lin J and Ujiie T. 1997. "Evaluation of the Antioxidant and Hepatoprotective Activity of Terminalia catappa,” Am J Chinese Med, 25:53-161. doi:10.1142/S0192415X97000172

Lorke D. 1983. A new approach to practical acute toxicity testing. ArchToxicolo, 54: 275-287.

Madu JO and Nadro M. 2017. Evaluation of the Toxicological effects of Senecio aureus extract on the liver and hematological parameters in wistar rats. Jordan J Bio Sci, 10: 29-32

Mccloud TG. 2010. High throughput extraction of plant, marine and fungal specimens for preservation of biologically active molecules. Molecules, 15:4526- 4563. doi:10.3390/molecules15074526.

Mohale DS, Dewani AP, Chandewar AV, Khadse CD, Tripathi ASand AgrawalSS. 2009. Brief review on medicinal potentials of Terminalia catappa. J Herb Med Toxicol,3: 7 - 11.ISSN:09734643

Mudi S and Muhammed A. 2009. Antimalaria activity of ethanolic extracts of leaf of Terminalia catappa L. combretaceae (Indian almond). Bayero J Pure Appl Sci, 2: 14-18. 
Nagappa AN, Thakurdesai NV, Raob JS. 2003. Antidiabetic activity of Terminalia catappaLin fruits. J Ethnopharmacol , 88:45-50

Odugbemi T. 2008. A Text Book of Medicinal Plant From Nigeria. University of Lagos Press, Yaba, Lagos.

Raj K, Mandeedn S, Nitesh G, Manoj K, Indu B and Shailendra NG. 2013. Prevalence of food intolerance in bronchial asthma in India. India $J$ Allergy, Asthma Immunolo, 27: 121-128. Doi:10.4103/0972-6691.124394

Ratnasooriya WD and Dharmasiri MG. 2000. Effects of Terminalia catappa seeds on sexual behavior and fertility of male rats. Asian J Adrology, 2(3):213 -219.doi:

Reitman S and Frankel S. 1957. A colorimetric method for the determination of serum glutamic oxaloacetic and glutamic transaminases. Am J Clin Path, 28: 56 - 63.

Shanehbandi D, Zariedar H, Asadi M et al. 2019. Anti cancer impacts of Terminalia catappa extract on SN 480 Colorectal Neoplasm cell line. J Gastrointes Cancer, 10: 17.doi:10.1007/s12029-019-00349-z.
Trease G and Evans SM. 2002. Pharmacognosy $15^{\text {th }}$ ed. London. Bailer Tindal. Pp23-67.

Venkatalakshmi P and Brindha P. 2016. Antimicrobial activity of aqueous extracts of different parts of Terminalia catappa L. Int. J. Curr. Microbiol App. Sci, 5(12): 493-498.

WHO (1998). Regulatory situation of herbal medicines a Worldwide Review. http;//www.who.int/medicineddocs/. Accessed, 20 $0^{\text {th }}$ April, 2020.

Wintrobe, P. K. (1967). Clinical Haematology. Williams and Wilkins, Lippincott

World Health Organization Dept. of Essential Drugs and medicine policy (2004). WHO guideline on safety monitoring of herbal medicines in pharmacovigilance systems, Geneva; WHO publishers, P18. http://www.who.int/iris/handle/10665/43034. Accessed 24th October, 2019

Yang SF, Cha MK, Hseih YS, Yang JS, Zauras AI and Hsei YH. (2010). Antimetastatic effects of Terminalia catappa L. on oral cancer via a donor regulation of metastasis-associated proteases. Food Chem Toxicol, 48(4):1052-1058.

Doi:10.1016/j.fct.2010.01.019 